MAŁGORZATA WYŻYKOWSKA

Instytut Socjologii UMK

\title{
Medialny wizerunek Jana Rokity
}

Drzyszło nam żyć w bardzo trudnych czasach. W kraju, w którym ponad trzy czwarte społeczeństwa uważało, że politycy są w większości nieuczciwi i niewiarygodni ${ }^{1}$. W kraju, w którym uczestnictwo w najbliższych wyborach parlamentarnych deklarowało tylko $44 \%$ obywateli ${ }^{2}$. Najczęstszą przyczyną tego typu deklaracji był brak zaufania do polityków i partii politycznych oraz brak motywacji do uczestniczenia w wyborach ${ }^{3}$. $Z$ danych tych wynika jednoznacznie, że opinie o polskiej klasie politycznej były bardzo złe, a większość polityków nie spełniała społecznych oczekiwań, co prowadziło do apatii wyborczej i zaniku poczucia podmiotowości obywatelskiej. Trudno też nie zgodzić się z tezą, że w ciągu ostatnich dwóch lat uległ znacznemu pogorszeniu i tak już negatywny wizerunek polityków w opinii społecznej ${ }^{4}$. Mimo, iż statystyki były mało optymistyczne, a kolejne afery na scenie politycznej przestały już dziwić kogokolwiek, to jednak byli w Polsce ludzie, którym obywatele powierzyli misję uzdrawiania państwa, dali swoje zaufanie i wiarę w to, że kiedyś obudzą się bez trosk.

Rosnąca od stycznia 2003 roku, niemal w błyskawicznym tempie popularność Jana Rokity wydawała się być początkiem długiego procesu odbudowywania zaufania dla klasy politycznej. Udział Jana Rokity w pracach sejmowej komisji śledczej przyczynił się do wzrostu jego popularności, a także do wzrostu społecznego zaufania. Nie ulega wątpliwości, że Rokita był polity-

\footnotetext{
${ }^{1}$ Komunikat z badań CBOS, Opinie o polskiej klasie politycznej, Warszawa, czerwiec 2003.

Komunikat z badań CBOS, „Nie wierze politykom” - Przyczyny deklarowanej absencji wyborczej, Warszawa, listopad 2004.

3 Tamże.

${ }^{4}$ Komunikat z badań CBOS, Opinie o polskiej klasie politycznej, dz.cyt.
} 
kiem rozpoznawalnym - prawdopodobnie w dużej mierze dzięki zainteresowaniu mediów jego osobą. Mimo iż krytykowali go rywale, to jednak eksperci od kreacji wizerunku oceniali go pozytywnie. Trudno oprzeć się wrażeniu, że jego czas już minął. Zdobył ogromną popularność, dziś jednak już nie jest liderem. Wynika to $\mathrm{z}$ faktu, iż wizerunek polityka można potraktować jako produkt polityczny, który przechodzi od fazy wprowadzenia na rynek, poprzez wzrost popularności, jej dojrzałość, a w konsekwencji jej spadek ${ }^{5}$.

Celem tej pracy jest uzyskanie odpowiedzi na pytanie: Jakie cechy powinien posiadać polityk, by tak, jak Rokita, zdobyć zaufanie społeczeństwa?

Wydaje się zasadne, by rozważania na temat wizerunku aktora sceny politycznej rozpocząć od wyjaśnienia terminu używanego przez Phillippe’a Brauda - „profil symboliczny”. Zdaniem autora, profil symboliczny to połączenie dwóch elementów: wizerunku osobistego oraz etykiety partyjnej. Taka prezentacja kandydata, zastępuje jego rzeczywistą tożsamość. Wizerunek osobisty kandydata musi z jednej strony pokazać go jako osobę bliską potencjalnym wyborcom, z drugiej zaś pokazać jego wyższość 6 . Znaczenie kandydata uzależnione jest również od popularności partii, która może być „rakietą nośną w przypadku normalnej kariery politycznej”. W przypadku Jana Rokity mieliśmy jednak do czynienia z sytuacją odwrotną. To on stał się „rakietą nośną" dla Platformy Obywatelskiej. Wraz ze wzrostem jego popularności można było zaobserwować wzrost popularności partii, której był liderem.

Wizerunek niewątpliwie musi być spójnym obrazem polityka, powinien uwzględniać cechy jego osobowości, wiedzę, a także jego cechy fizyczne. Nie można jednak zapomnieć, że zawsze będzie to obraz uogólniony, co oznacza, że w taki właśnie sposób jest polityk postrzegany ${ }^{8}$. Polityk musi więc mieć swój image, na który składa się nie tylko opinia wyborców na jego temat, ale także wyobrażenie o jego cechach ${ }^{9}$. Trudno nie zgodzić się zatem $z$ tezą, że wizerunek podlega różnego rodzaju regułom marketingowym, czyli tak naprawdę w tym przypadku nie człowiek jest ważny, lecz wrażenie, jakie na kimś wywiera ${ }^{10}$.

\footnotetext{
${ }^{5}$ M. Cichosz, (Auto)kreacja wizerunku polityka na przykładzie wyborów prezydenckich $w$ III RP, Toruń 2003, s. 60-61.

${ }^{6}$ Tamże, s. 210-211.

7 Tamże, s. 214.

${ }^{8}$ R. Wiszniowski, Wprowadzenie do teorii marketingu politycznego, w: Marketing polityczny $w$ teorii $i$ praktyce, A. W. Jabłoński, L. Sobkowiak (red.) Wrocław 2002, s. 57.

9 W. Gałązka, A. Krywicki, Nie wystarczy być... czyli od zera do lidera, Wrocław 2004, s. 140.

${ }^{10}$ A. Drzycimski, Sztuka dyskretnego podpowiadania i pośrednictwa, w: Komunikatorzy, red. tenże, Warszawa 2000, s. 33.
} 
Analizom tu przeprowadzonym poddane zostały artykuły prasowe na temat Jana Rokity, które ukazały się na łamach dziennika „Rzeczpospolita” między styczniem 2003 roku a wrześniem 2004 roku. Jest to okres, w którym prowadziła swoją działalność sejmowa komisja śledcza ds. zbadania ujawnionych w mediach zarzutów dotyczących przypadków korupcji podczas prac nad nowelizacją ustawy o radiofonii i telewizji.

Do analizy zostało wybranych 121 wypowiedzi, które umożliwiły określenie tego, jaki jest medialny wizerunek polityka. Wśród analizowanych wypowiedzi znalazły się zarówno te o charakterze neutralnym, jak i ocennym.

W celu uzyskania przejrzystej analizy wprowadziłam cztery kategorie analityczne: przeszłość, wygląd zewnętrzny, cechy osobowości oraz stosunek do rzeczywistości.

\section{Przeszłość}

Rokita swoje dzieciństwo i młodość określał jako szczęśliwe życie. Został wychowany przez same kobiety, skrzywdzony przez los i komunizm. Bardzo dużo czytał i śpiewał w chórze. To dzięki sprytowi i wykorzystaniu socjotechniki radził sobie z chuliganami, nauczycielami i profesorami. Działalność publiczną rozpoczął po sierpniu 1980 roku w Niezależnym Zrzeszeniu Studentów Uniwersytetu Jagiellońskiego. Kiedyś był radykałem. Przełom lat 80. i 90. upłynął na działalności w Komitecie Obywatelskim przy Lechu Wałęsie. Później udzielał się przy młodzieżowym Stoliku Okrągłego Stołu u boku Andrzeja Celińskiego. Był też wiceprzewodniczącym Obywatelskiego Klubu Parlamentarnego, a następnie przewodniczącym komisji do zbadania działalności Ministerstwa Spraw Wewnętrznych. To z jego ust padały hasła nawołujące do rozliczenia komunistów. Za czasów rządów Hanny Suchockiej był szefem Urzędu Rady Ministrów ${ }^{11}$.

Gdy w październiku 2002 roku poniósł klęskę w wyborach na prezydenta Krakowa wydawało się, że „odchodzi w polityczny niebyt” ${ }^{12}$. Uratował go jednak wybór do sejmowej komisji śledczej badającej aferę Rywina ${ }^{13}$. Według specjalistów od wizerunku jest osobą wzbudzającą sympatię, bo ma nieskażoną przeszłość i nie ciągną się za nim żadne afery ${ }^{14}$. Przeszłość Rokity jest więc jego atutem. Mimo, że jest uznawany za rekordzistę, jeśli chodzi o liczbę „zaliczonych partii" ${ }^{15}$, to jednak wpływa to pozytywnie na jego wizerunek.

\footnotetext{
${ }^{11} \mathrm{~K}$. Gottesman, Rokity portret własny, „Rzeczpospolita”, 08.05.2004.

${ }^{12}$ L. Zalewska, Najlepszy i najpiękniejszy, ,Rzeczpospolita”, 23.07.2003.

${ }^{13}$ Prezes telewizji do zawieszenia, „,Rzeczpospolita”, 11.02.2003.

${ }^{14}$ L. Zalewska, Najlepszy i najpiękniejszy, dz.cyt.

${ }^{15}$ Prezes telewizji do zawieszenia, dz.cyt.
} 


\section{Wygląd zewnętrzny}

Według tygodnika „Gala” należał w 2003 roku do pięćdziesięciu najpiękniejszych Polaków. Na liście tej znalazł się jako „dociekliwy detektyw i nieustraszony tropiciel korupcji”"16. Rokita wybór tygodnika „Gala” wyjaśnił takimi oto słowami: ,jest to przekonującym dowodem na to, że najseksowniejszy w człowieku jest mózg"17. Trudno nie oprzeć się wrażeniu, że w stwierdzeniu tym da się wyczuć nutkę kokieterii.

Krzysztof Nowak - dyrektor agencji PR Profile, wygląd zewnętrzny Rokity określił w następujących słowach: ,jest to bardzo charakterystyczna postać: nosi kapelusze, elegancko się ubiera, co lubią kolorowe pisma"18. Dlatego też jego twarz wraz z żoną i córką bardzo często pojawia się na okładkach kolorowych pism. Zdawał sobie sprawę z tego, że ma znaną twarz. Uważał, że czasami ma to swoje dobre strony, gdyż ludzie okazują wiele życzliwości. Jednak, gdy jest się rozpoznawalnym, to zdarza się, że jest to uciążliwe $^{19}$. Rokita jednak wcale nie ukrywał, że taka popularność jest dla niego korzystna. Jego zdaniem „sztuka sprawowania dobrego przywództwa polega na byciu z własnym ludem"20.

Analizowane wypowiedzi nie poruszały zbyt często kwestii wyglądu zewnętrznego Rokity. Może wynika to ze specyfiki tego medium. Wydaje się, że wygląd zewnętrzny może być raczej przedmiotem zainteresowania kolorowych pism. Może to cechy osobowości przykuwają większą uwagę dziennikarzy. Być może, to właśnie jego wypowiedzi i sposób oceniania otaczającej rzeczywistości był jego znakiem rozpoznawczym. Chciałabym więc w tym miejscu poruszyć jedną kwestię, która wprawdzie nie jest inspiracją płynącą z artykułów „Rzeczpospolitej”, jednak ma moim zdaniem duże znaczenie. Dość charakterystyczny jest strój Rokity, zawsze elegancki i dostosowany do sytuacji. Charakterystyczny jest też wybór koloru - króluje czerń. Zdaniem specjalistów, kolory mogą budzić sympatię lub antypatię, zaufanie lub jego brak $^{21}$. Barwy ubiorów mogą być wskazówką do rozpoznania typów ludzkich oraz sposobem oddziaływania na innych ${ }^{22}$. Kolor czarny symbolizuje autorytet oraz wiarygodność, ale także stałość i samotność.

\footnotetext{
${ }^{16}$ L. Zalewska, Najlepszy i najpiękniejszy, dz.cyt.

${ }^{17}$ Tamże.

${ }^{18}$ Tamże.

${ }^{19}$ M. Subotić, Lepsze Bieszczady niż Paryż, „Rzeczpospolita”, 06.07.2004.

${ }^{20} \mathrm{~K}$. Gottesman, dz.cyt.

${ }^{21}$ W. Gałązka, A. Krywicki, dz.cyt., s. 77.

${ }^{22}$ Tamże, s. 79 .
} 


\section{Cechy osobowości}

Rokita jest znany z „przenikliwej inteligencji i sprawności retorycznej”23. Jest także oczytany, co stanowi rzadkość u polskich polityków ${ }^{24}$. Ma niezwykłą zdolność analizy, ale bardzo lubi eksponować swoją przewagę intelektualną 25 .W rozmowie lubi być prowokatorem, jest to jego taktyka, by uczynić dyskusję bardziej twórczą. Dlatego też często odbierany jest jako arogant. Podczas dyskusji w szerszym gronie często nudzi się i zaczyna wtedy nucić fragmenty ulubionych oper, co zapewne wpływa deprymująco na rozmówców ${ }^{26}$. Mimo to uważany był często za niezwykle groźnego i inteligentnego przeciwnika ${ }^{27}$, który posługiwał się „żelazną logiką"28.

Talent Rokity jako śledczego w sejmowej komisji pomógł mu zająć pozycję lidera Platformy Obywatelskiej ${ }^{29}$. Zabłysnął inteligencją, dociekliwością, odwagą i pracowitością ${ }^{30}$. Z przesłuchań robił widowiska - na wypowiedzi świadków reagując często celnymi komentarzami lub charakterystycznymi minami ${ }^{31}$. Zdaniem Tomasza Żukowskiego, „dzięki komisji śledczej stał się bardzo popularnym politykiem, także wśród wyborców, którzy popierają hasła sprawiedliwości i prawa" ${ }^{32}$. Stał się gwiazdą komisji śledczej, cieszącą się społecznym zaufaniem ${ }^{33}$. Jest jednak politykiem, któremu nie zależy na kulcie popularności. Doskonale zdaje sobie sprawę, że owa popularność jest niezwykle chwiejna, jednak bez niej nie można skutecznie niczego osiągnąć w polityce ${ }^{34}$.

Sam mówił o sobie, że ,jeśli się w coś angażuję to na sto procent, z otwartą przyłbicą. Wchodzę z hukiem, główną bramą i nie patrzę na boczne wyjścia" ${ }^{35}$. Nikogo nie dziwi więc, że do pracy w komisji przygotowywał się nawet kilkanaście godzin dziennie, uczył się też rozmawiając z prawnikami, biznesmenami z branży medialnej, a nawet z psychiatrami. Każdemu zadaniu, które uzna za ważne, potrafi poświęcić maksimum czasu

\footnotetext{
${ }^{23}$ Prezes telewizji do zawieszenia, dz.cyt.

${ }^{24}$ M. Subotić, Na obraz i podobieństwo swoje, „Rzeczpospolita”, 05.04.2003.

${ }^{25}$ Tamże.

${ }^{26}$ Tamże.

${ }^{27}$ P. Semka, Lekcje do odrobienia, „Rzeczpospolita”, 06.10.2003.

${ }^{28}$ Sukcesy i klęski 2003, „Rzeczpospolita”, 31.12.2003.

${ }^{29}$ L. Zalewska, Alfabet afery Rywina, ,Rzeczpospolita”, 29.12.2003.

${ }^{30}$ P. Śmiłowicz, Pierwsze starcie, „Rzeczpospolita”, 15.03.2004.

${ }^{31}$ Sukcesy i klęski 2003, dz.cyt.,

${ }^{32}$ L. Zalewska, Alfabet afery Rywina, dz.cyt.

${ }^{33}$ Kolejny tytuł dla Rokity, ,Rzeczpospolita”, 06.01.2004.

${ }^{34} \mathrm{~K}$. Groblewski, Jestem prawnikiem z marzeń, „Rzeczpospolita”, 27.10.2003.

${ }^{35} \mathrm{M}$. Subotić, Na obraz i podobieństwo swoje, dz.cyt.
} 
i energii, zamieniając się wtedy w „mrówkę” ${ }^{36}$. Uznanie dziennikarzy zdobył dzięki niebywałej pracowitości i aktywności w komisji śledczej ${ }^{37}$. Dość trafne wydaje się określenie, że był "detektywem Rutkowskim dla inteligencji”"38.

Był i jest jednym z najwybitniejszych polityków, jednak traktuje ludzi z góry, przez co nie potrafi współpracować na partnerskich warunkach ${ }^{39}$. Zdaniem współpracowników ma dyktatorskie skłonności, obraża często ludzi, a jego krytyka przypomina „wdeptywanie w ziemię" ${ }^{40}$. Pojawiają się też opinie, że jest on destruktorem, który nie potrafi pracować w zespole ${ }^{41}$. Jest szefem, nie partnerem, partnerstwo jest dla niego pojęciem nieznanym ${ }^{42}$. Stąd może jego „reputacja solisty, który jest dobry do błyszczenia na posiedzeniach komisji" ${ }^{43}$.

Rokita nigdy nie kłamie. Uważa, że „żyjemy w czasach, w których szczerość i otwartość jest bardzo ważna. Czasy kardynałów Richelieu minęły" ${ }^{\prime 4}$. Lubił dodawać sobie trochę ważności i okazywać się sprytniejszy niż uznawane autorytety ${ }^{45}$. Charakteryzuje się krasomówstwem, lubi triumfować, chce mieć zawsze rację i to nie tylko w polityce ${ }^{46}$.

\section{Stosunek do rzeczywistości}

Polityka to dla niego "najbardziej wysublimowanym sposobem oddziaływania na rzeczywistość", tak jak dla Arystotelesa - jego ulubionego filozofa $^{47}$. Interesują go tylko wielkie rzeczy, takie jak udział w realnej władzy ${ }^{48}$. Sam mówił o sobie, że „polityk, który nie chce być premierem dyskwalifikuje samego siebie. Każdy, kto przychodzi do polityki - nie dlatego, że jest oportunistą, bądź chce się obłowić - kieruje się motywacją stricte polityczną, czyli chęcią oddziaływania na rzeczywistość" ${ }^{49}$. W polityce jednak najważniejsza jest dla niego lojalność. Uważał wprawdzie, że jest ona rzeczą

\footnotetext{
${ }^{36}$ Tamże.

${ }^{37}$ L. Zalewska, Najlepszy i najpiękniejszy, dz.cyt.

${ }^{38}$ S. Sierakowski, Albo Argentyna, albo maj “68, „Rzeczpospolita”, 22.03.2004.

${ }^{39}$ M. Subotić, Na obraz i podobieństwo swoje, dz.cyt.

${ }^{40}$ Tamże.

${ }^{41}$ F. Gawryś, P. Śmiłowicz, Platforma konserwatywna, „Rzeczpospolita”, 18.12.2003.

${ }^{42}$ M. Subotić, Na obraz i podobieństwo swoje, dz.cyt.

${ }^{43}$ P. Semka, Rzad fachowców, czyli droga donikad, „Rzeczpospolita”, 19.03.2003.

${ }^{44}$ F. Gawryś, P. Śmiłowicz, dz.cyt.

${ }^{45}$ K. Gottesman, dz.cyt.

${ }^{46}$ Tamże.

${ }^{47}$ M. Subotić, Na obraz i podobieństwo swoje, dz.cyt.

${ }^{48}$ Tamże.

${ }^{49}$ Tamże.
} 
trudną, ale bez niej nie można uprawiać polityki, bo nie jest ona zajęciem indywidualnym ${ }^{50}$.

W polityce dokonywał przede wszystkim wyborów pragmatycznych, ale jego poglądy są „konserwatywno-liberalne: liberalne w sferze gospodarczej, konserwatywne w pozostałych" ${ }^{11}$. Uważał, że istnieje obecnie w Polsce zapotrzebowanie społeczne na przełom konserwatywny, na który składa się: wzmocnienie instytucji publicznych, twarde respektowanie nakazów moralnych oraz restrykcyjność państwa ${ }^{52}$. Zainspirowany Platonem stwierdza, że polityka składa się „ze słowa zdolnego przewodzić duszom”. ${ }^{53}$. Jego zdaniem, jeżeli polityk nie jest zdolny do obrony własnych racji, powinien natychmiast odejść z polityki ${ }^{54}$. Uczestnictwo w polityce według niego nie polega jednak na ujawnianiu wszystkich swoich przekonań i sądów na temat innych ${ }^{55}$.

Myślą przewodnią jego wywodów o sobie, o historii a także i o przyszłości było państwo. Silne państwo, to silna i niepodzielna władza wykonawcza $^{56}$. Jest „państwowcem”, pojęcie państwa jest dla niego najważniej$\mathrm{sze}^{57}$. Stąd zapewne bierze się jego specyficzny stosunek do demokracji. Uważał, że jeśli demokracja prowadzi do słabości państwa, to tym gorzej dla niej ${ }^{58}$. Polityka demokratyczna, to dla niego „ustawiczne staranie się o budowanie, odbudowywanie, powiększanie zaufania społecznego"59. Sprawność i oszczędność w sprawowaniu władzy jest dla niego ważniejsza od „mitu obywatelskiego"60.

Uważał się za zwolennika pojmowania zasady konfliktu interesów w sposób bardzo rygorystyczny. „W moim przekonaniu łączenie dwóch funkcji powinno być wykluczone, niezależnie od tego czy prawo to przewiduje, czy nie" ${ }^{61}$. Źle ocenia ilość prawa w naszym kraju, jak i proces jego tworzenia $^{62}$.

Udział w pracach komisji śledczej traktował jako wyzwanie zawodowe, gdyż była to „przygoda prawnicza i eksperyment ustrojowy, który polega na

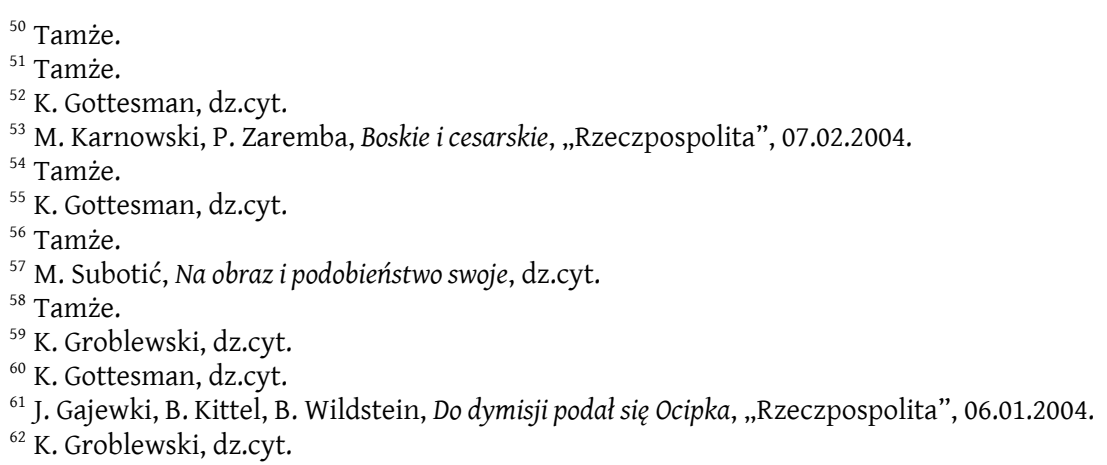


tym, że parlament wchodzi w obszar tradycyjnych kompetencji prokuratury, wymiaru sprawiedliwości i organów ścigania"63.

Jan Rokita był niewątpliwie „lokomotywą, która dźwignęła Platformę na sondażowe wyżyny" ${ }^{64}$. „Zabrał też sporo wiatru z żagli Lecha Kaczyńskiego" ${ }^{65}$. „Darem opatrzności” stał się dla niego udział w sejmowej komisji śledczej, dzięki której zdobył popularność ${ }^{66}$. „W turnieju na sentencje otrzymałby plamę pierwszeństwa, wieniec i różę za parafrazę Fidela Castro - «Nicea o muerte»". Hasło "Nicea albo śmierć” stało się więc kolejnym źródłem jego popularności. Zdobył wiele prestiżowych nagród, między innymi tytuł Człowieka Roku 2003 przyznawany przez tygodnik „Wprost” oraz jako pierwszy został laureatem Nagrody im. Edwarda J. Wendego.

Jednoznaczne określenie, z jakim typem wizerunku mamy do czynienia, w przypadku Jana Rokity, wydaje się niemożliwe. Z jednej strony można go uznać za „eksperta" ${ }^{67}$. Jest bowiem osobą odpowiedzialną i skuteczną, posiadającą szeroką wiedzę. Jednocześnie to człowiek wiarygodny i rzetelny, co potwierdza fakt, iż połowa społeczeństwa obdarzyła go zaufaniem ${ }^{68}$. Z drugiej jednak strony, trudno nie oprzeć się wrażeniu, że można by uznać Rokitę za „herosa”" metody działania, eksponując przy tym swoją przewage intelektualną. W tej sytuacji określenie Rokity „charyzmatycznym przywódcą” nie wydaje się stwierdzeniem na wyrost. Można by też uznać go za „idola"70, gdyż niewątpliwie jest konsekwentny i posiada zdolność podejmowania decyzji.

Na początku pracy postawiłam pytanie - jakie cechy powinien posiadać polityk, by tak jak Rokita, zdobyć zaufanie społeczeństwa? W myśl powyższych rozważań należałoby wymienić następujące cechy: nieskażoną przeszłość, charakterystyczny wygląd: elegancki, najlepiej czarny i dostosowany do sytuacji ubiór, powagę, inteligencję, dociekliwość, odwagę, pracowitość, zaangażowanie, szczerość, otwartość i przede wszystkim udział w pracach komisji śledczej. Trudno jednak jednoznacznie określić, które z powyższych cech wywołują sympatię, a które skazują na polityczny niebyt. Czy wystarczy nieskazitelna przeszłość, atrakcyjny wygląd i odpowiednie cechy

\footnotetext{
${ }^{63}$ Tamże.

${ }^{64}$ W. Kaczyński, Wędrówki wyborczego ptactwa, „Rzeczpospolita”, 24.02.2004.

${ }^{65}$ Tamże.

${ }^{66}$ M. Subotić, Na obraz i podobieństwo swoje, dz.cyt.

${ }^{67}$ M. Jeziński, Marketing polityczny a procesy akulturacyjne. Przypadek III Rzeczpospolitej, Toruń 2004, s. 138.

${ }^{68}$ Komunikat z badań CBOS, Zaufanie do polityków w przededniu rozłamu SLD, Warszawa, marzec 2004.

${ }^{69}$ M. Jeziński, dz.cyt., s. 138.

${ }^{70}$ Tamże, s. 139.
} 
osobowości? Pytanie - które cechy gwarantują polityczny sukces? pozostawię jednak bez odpowiedzi. Nie ulega jednak wątpliwości, że Jan Rokita był i jest osobą znana i rozpoznawalną. W styczniu 2004 roku został obdarzony zaufaniem ponad połowy społeczeństwa ${ }^{71}$, co może oznaczać, że jego wizerunek był pozytywnie odbierany przez obywateli. Dla dość znacznej części społeczeństwa był niewątpliwie autorytetem i wzorem, może nawet „idealnym politykiem”, spadek jego popularności jest jednak dowodem na to, że w polityce każdy ma swoje „pięć minut”.

M A Ł G O R Z A T A W Y Ż Y K O W S K A

${ }^{71}$ Komunikat z badań CBOS, Zaufanie do polityków w styczniu, Warszawa, luty 2004. 


\section{Jan Rokita's image in Polish media}

A negative likeness of many politicians has changed for the worse during the last years. Nevertheless there are some politicians whom our community charge a mission connected with improving our nation. Jan Rokita is a politician who had gained huge popularity and trust among his citizens. What kind of feature should has politician to be able to attain so much trust as Jan Rokita? Newspaper articles combine with Jan Rokita has been analysed to this end. These were presented at "Rzeczpospolita" from 2003 to 2004. There were analysed 121 statements, which enabled to describe how Jan Rokita mediumistic likeness was. Jan Rokita likeness was describe here on four categories: the past, appearance, personality and attitude towards reality. According to carried out analysis we can notice that Jan Rokita is recognizable and well-known person. Rokita made a good impression on his citizens throughout his image. He was enjoyed respect and was followed as an example for many Poles. However it is difficult to answer interchangebly - what personality trait ensure us to be successful in politics. Jan Rokita has been loosing his popularity undoubtedly, what shows that everyone has a bid fair to succeed in politics at the given moment. 